\author{
Jan Szczepankiewicz \\ Krajowe Forum Przedsiębiorczości, Kraków
}

\title{
Szczególna rola polskiej przedsiębiorczości w okresie przeobrażeń cywilizacyjnych współczesnego świata
}

Cywilizacja na świecie zawsze rozwijała się wielotorowo i była silnie zróżnicowana. Tak było w starożytności, w wiekach średnich, w czasach burzliwego rozwoju techniki i wbrew pozorom postępującej unifikacji - tak jest współcześnie. Jeżeli tę wielotorowość mniej zauważamy, to tylko dlatego, że funkcjonujemy w obrębie naprawdę dużej, wciąż dominującej i szybko globalizującej się cywilizacji atlantyckiej.

Klasyk liberalizmu, Monteskiusz dawno już zauważył, że posługując się metodami historyczną i geograficzną można łatwo wytłumaczyć zróżnicowanie systemów wartości, panujących ustrojów i stopnia rozwoju poszczególnych obszarów Ziemi.

Mimo postępującej na obszarze funkcjonowania naszej cywilizacji degradacji tego, co było jej pierwotna podstawą, czyli dobrej, starej cywilizacji łacińskiej, my Polacy mamy wrażenie, że znajdujemy się oto wreszcie w centralnym nurcie światowego rozwoju. W towarzystwie narodów zamożnych, tworzących i konkurujących na linii Unia Europejska USA. Nie przeszkadza nam nawet to, że Unia Europejska, do której wstąpiliśmy, nigdy nie zrealizuje założeń tzw. Strategii Lizbońskiej, stosując preferowane mechanizmy centralnego sterowania, redystrubucji i rozwijając dalej pasożytującą wszędzie biurokrację. Już dziś praktycznie się ona nie rozwija, a wiele państw członkowskich wykazuje tendencje charakterystyczne dla czasów tych schyłkowych cywilizacji, które przegrały, przechodząc do historii.

Cieszymy się jednak, że oto po okresie realnego socjalizmu możemy wreszcie bywać na wciąż bogatych i preferujących dość humanitarne metody europejskich salonach, jednocześnie zachowując bardzo dobre stosunki z państwem, szczególnie u nas dobrze postrzeganym - ze Stanami Zjednoczonymi Ameryki Północnej.

I rzeczywiście, ten drugi element naszej orientacji jest szczególnie wartościowy, gdyż płynące zza Atlantyku nauki sprzyjają rozwojowi prawdziwej wolności gospodarczej i przedsiębiorczości. Ocena ta wynika $\mathrm{z}$ analizy polityki handlowej, polityki fiskalnej państwa, poziomu interwencji tegoż państwa w procesy gospodarcze, swobody przepływu kapitałów, sytuacji inwestorów w tym zagranicznych, finansów i bankowości, cen i płac oraz rozmiarów szarej strefy i obszarów czarnego rynku.

Także mentalne nastawienie Amerykanów, preferujące liberalne zasady funkcjonowania społeczeństwa, a więc indywidualizm, wolność osobistą, swobodę gospodarowania, życiową zaradność i inicjatywę oraz obywatelski stosunek do własnego państwa wydają się być szczególnie dla nas wartościowe w okresie ciągle jeszcze trwającej u nas transformacji systemowej.

Tu w Europie, dwa państwa, które forsowały i finansowały powstanie Unii Europejskiej w obecnym kształcie, a więc Francja i Niemcy pogrążyły swoje gospodarki, stosując nieefektywne, wręcz zabójcze dla swej przyszłości modele.

Według oceny analityków i ekonomistów Haritage Fundation państwem najmniej konkurencyjnym, a więc najbardziej nieprzyjaznym przedsiębiorczości jest właśnie Francja, 
zaś Niemcy określane mianem „chorego człowieka Europy”, po długim okresie stagnacji zanotowały wreszcie na początku 2004 roku wzrost gospodarczy raptem 2 procentowy.

Mimo to obydwa te kraje są nadal oczywiście o wiele bogatsze od Polski, a ich produkt krajowy brutto jest nieporównywalnie większy. Zawdzięczają to minionemu okresowi zachowań gospodarczych bardzo przyzwoitych, a z gruntu odmiennych od obecnych.

Pierwsze miejsce pod względem realizacji wolności gospodarczej mają niezmiennie USA, Hong Kong i Singapur, zaś z krajów europejskich najwyżej notowane są: Wielka Brytania i Irlandia. Światowe Forum Gospodarcze pozytywnie oceniło też systemy Finlandii i Estonii.

Prawdziwą lokomotywą postępu naszego świata są obecnie Stany Zjednoczone i to one z całą pewnością wygrają w ewentualnej konkurencji z socjalistyczną Unią Europejską, tym bardziej, jeżeli nie uda się doprowadzić do zmiany jej obecnego charakteru. Ale tak naprawdę ta konkurencja ma istotne, ale wtórne znaczenie $\mathrm{w}$ dłuższej perspektywie i prawdziwy cywilizacyjny przełom wydaje się być nieunikniony w wyniku rozwoju państw leżących od nas - na Wschód.

Zacznijmy od Federacji Rosyjskiej, która jest państwem tradycyjnie źle przez Polaków odbieranym z powodów historycznych i kulturowych, bardzo dla nas ważnym i dalej mało przyjaznym.

Przez ostatnie lata, mimo okresów tragicznych załamań, jak choćby to z roku 1998, zdołało ono faktycznie zneutralizować buforową dla nas Białoruś i rozbudować swe wpływy w strategicznie traktowanej, suwerennej Ukrainie. Rosja kusi też kraje unijne koncesjami gospodarczymi.

Istnieją w niej kolosalne obszary nędzy, groźnie rozpada się imperialna armia, rozbudowała się jedynie klasa bardzo bogatych. Faktem jest istotne jej uzależnienie od światowych cen ropy i gazu. Obserwowaliśmy w Rosji, właściwie przez całą dekadę lat 90-tych, ogromną zapaść ekonomiczną, społeczną i polityczną. Mimo to obecnie Rosja dźwiga swoją gospodarkę i odnotowuje w ostatnich 5 latach, przeciętny wzrost gospodarczy rzędu $6 \%$. W 2003 roku wynosił on 7,3\%, a w pierwszym półroczu 2004 r. $-8,4 \%$.

Jednocześnie w 2003 roku jej zadłużenie spadło z 93 do 28\% PKB, a rezerwy walutowe wzrosły z 8 do 80 mld. dolarów. Po raz pierwszy od rewolucji 1917 r. kraj ten zdołał wyeksportować zboże. Dzieje się to przy potężnym wpływie polityki na sferę gospodarki, faktycznym panowaniu monopoli, przy rzeczywistych rozmiarach gospodarki rosyjskiej porównywalnej z wielkością gospodarki malutkiej Holandii. Tak m.in. zadziałało wprowadzenie rynkowych zasad i 13 procentowego podatku liniowego.

Należy zauważyć, że licząc na demokratyczne przemiany w tym kraju, USA wpompowały $\mathrm{w}$ gospodarkę rosyjską $\mathrm{w}$ przeciągu 7 lat 20 mld. dolarów, forsując $\mathrm{w}$ instytucjach międzynarodowych korzystne dla niej rozwiązania. Mimo to, wierna swej niechlubnej, imperialnej tradycji Rosja nadal dozbraja kraje im wrogie, ani myśli przestrzegać elementarnych praw człowieka i utrzymuje bardzo niebezpieczny, jeden z dwóch największych na świecie arsenał nuklearny. Jej władze nie zamierzają też rozliczyć swej historycznej, zbrodniczej spuścizny, hasło jawności pozostało jedynie postulatem historycznym, zaś nieudolność aparatu państwowego zawsze skutkuje tradycyjnymi dla cywilizacji Wschodu ofiarami pogardzanego tam ludzkiego życia.

Mimo wyrazów zadowolenia płynących z oficjalnych przemówień naszego Prezydenta i Premierów trudno uznać postępy strony rosyjskiej, w takim układzie za zadawalające $\mathrm{i}$ bezpieczne $\mathrm{z}$ naszego punktu widzenia.

Pomimo tych ciągłych perturbacji Bank Inwestycyjny Goldman Sachs przewiduje, że za 40 lat gospodarka rosyjska będzie i tak największą gospodarką Europy, a w roku 2050 przerośnie łączny potencjał gospodarczy włoski i niemiecki. Z uznaniem wypowiadają się o postępach Rosji zachodni analitycy choćby z Deutche Bank, czy Reiffeisen Central Bank z Wiednia. 
Dla nas ten kraj, ze swym potencjalnie atrakcyjnym rynkiem pozostaje niebezpiecznym i nieprzewidywalnym partnerem.

Dalej na wschód leżą Chiny. Państwo Środka ma obecnie imponujący wzrost gospodarczy i wynosi on w ostatnich latach blisko $10 \%$. Jeżeli jego tempo zostanie utrzymane, to za 15 lat państwo to stanie się największym producentem na świecie. Efekty te osiągnięto przy zachowaniu ideologicznej podstawy sprawowania władzy przy jednoczesnym, ograniczonym, lecz bardzo zdecydowanym wprowadzeniu zasad wolnego rynku.

Pamiętając o tym, że w niedawnej przeszłości funkcjonujący tam nadal system komunistyczny pochłonął życie $200 \mathrm{mln}$. więźniów politycznych, a tylko wg oficjalnych danych wykonuje się tam ponad 1800 wyroków śmierci rocznie, co stanowi 63\% egzekucji na całym świecie, musimy mieć na względzie, że chętnie współpracujący z obecnymi władzami Chin ludzie z wolnego dziś świata, po osiągnięciu przez ten kraj szczytu potęgi gospodarczej nie będą już mogli o żadne prawa człowieka się upominać. Mało tego, już dziś państwo to dysponuje m.in. $20 \%$ czołgów całego świata i samolotami w ilości ponad 6000 szt. Może też powołać pod broń $185 \mathrm{mln}$. rezerwistów.

Plac Niebiańskiego Spokoju stał się kolejnym symbolem zarówno komunistycznego barbarzyństwa, jak i nieskuteczności mechanizmów światowej demokracji - w obliczu bezwzględnego funkcjonowania totalitarnych systemów, a także możliwego do osiągnięcia dużego, a niebezpiecznego w dalszej perspektywie zysku. Dziś Chiny wydają się być jednym wielkim więzieniem, którym zawiaduje wyrachowany, cyniczny, kulturowo nam obcy aparat. Świat zarabia i woli jednak tego nie zauważać.

Od 2003 r Chiny są członkiem WTO. Czy międzynarodowe kontakty i wzrost zamożności niektórych warstw wpłyną na zmianę systemu i sposobu sprawowania władzy? Dziś, podobnie jak w przypadku Rosji czy krajów Bliskiego Wschodu, wydaje się to być prawie niemożliwe.

Bliski Wschód mimo olbrzymich zysków osiąganych ze sprzedaży ropy naftowej, stanowi dziś dla naszej cywilizacji bardziej zagrożenie i wyzwanie niż obszar inwestycji czy nadziei. Niezwykle pilną sprawą jest to, by politycy skutecznie nie tyle wprowadzili tam system demokratyczny, co zlikwidowali źródła szkodliwego, żerującego na zacofaniu cywilizacyjnym tego regionu terroryzmu. Pożywką jego są nierozwiązane, podobnie jak w przypadku Czeczenii, problemy polityczne, zapóźnienia cywilizacyjne i ekstremizm religijny. Jako fakt pozytywny należy jednak odnotować duże postępy gospodarcze Turcji, jej przynależność do NATO oraz dążenie do wejścia w europejskie struktury Unii. A leży ona przecież aż w 98\% - w Azji.

Jak na tym tle rysuje się Polska gospodarka, polska przedsiębiorczość, polskie szanse na sukces w przyszłości?

Otóż z całą pewnością polska gospodarka jest oceniana jako mało konkurencyjna. $\mathrm{Na}$ 102 klasyfikowane kraje wg oceny Światowego Forum Gospodarczego, plasowała się ona w 2003 roku na 45 miejscu. Awans z 50 pozycji był efektem ostatnich, pozytywnych zmian. M. in. nasz kraj notuje 5-6\% wzrost gospodarczy, podnosi się wydajność pracy, rosną płace realne, a od grudnia 2002 r. zwiększają się też zamówienia w sektorze publicznym.

Mimo pozytywnego trendu ostatnich dwóch lat należy powiedzieć, że nasz potencjał jest niewykorzystany głównie $\mathrm{z}$ powodu utrudnień $\mathrm{w}$ funkcjonowaniu rodzimych przedsiębiorstw. Podatki są wysokie, a sam system podatkowy jest skomplikowany i represyjny. Wysokie są koszty pracy, drogie przymusowe ubezpieczenia, panoszy się korupcja.

Polska ma najniższy wskaźnik zatrudnienia w UE i w lipcu 2004 r. w polskich urzędach pracy było zarejestrowanych aż $3 \mathrm{mln}$. 42 tys. bezrobotnych, a tylko 51,2 Polaków wykazuje stałe, legalne dochody $\mathrm{z}$ tytułu zatrudnienia. W tej sytuacji kolejny pomysł rządu, by ratować budżet podwyższając składki na ZUS, przy uldze $50 \%$ dla przedsiębiorców po raz pierwszy od 60-ciu miesięcy zakładających firmy, nie spowoduje wzrostu przedsiębior- 
czości i może tylko wywołać efekt tzw. "martwych urodzin", czyli sztucznego tworzenia zamykanych później firm. Także pomysł na karanie tych o najwyższych dochodach $-200 \%$ składką jest nie do przyjęcia. Głośno protestują więc organizacje przedsiębiorców, nie chcąc, by znowu zakorzeniony w Polakach instynkt przetrwania prowadził do patologii zatrudnienia, omijania prawa czy choćby rozwoju szarej strefy.

Reasumując, należy stwierdzić, że Polska, leżąc niezmiennie w Europie, od wieków stanowiąc tej Europy przedmurze, będąc dziś częścią określonych struktur ma do spełnienia niezwykle ważną misję. Ponieważ, jak widzimy, rywalizacja między państwami odbywa się dziś głównie na płaszczyźnie gospodarczej - nie musimy tego robić bezinteresownie. Wręcz przeciwnie, zachowując się egoistycznie, a przy tym racjonalnie możemy tylko zyskać na potwierdzaniu twardego stanowiska wobec socjalistycznych, szkodliwych gospodarczo i społecznie tendencji, które obecną Europę i jej Unię sprowadziły z drogi rozwoju i zdrowej chrześcijańskiej tradycji. Opierając się na tym, co u nas się wielokrotnie sprawdziło, a więc na pielęgnowanych więzach rodzinnych, upartym patriotyzmie i wykazywanej podczas wielu historycznych zawieruch odporności i pomysłowości, możemy wpłynąć na zachowania wewnętrzne i zewnętrzne słabnącej Europy. Polacy po roku 1989 wykazali naprawdę imponującą przedsiębiorczość i gdyby polityka władz, zwłaszcza wobec małego i średniego biznesu, była bardziej przychylna, gdyby obniżono i uproszczono podatki, wprowadzając choćby kilkunastoprocentowy podatek liniowy, odciążono budżet, redukując pasożytująca na nim biurokrację, w zupełnie inny sposób moglibyśmy wchodzić do UE. Przed nami następne wyzwania. Bazując na zachowanej części suwerenności i nabytych uprawnieniach w ramach funkcjonowania $\mathrm{w}$ organach unijnych, Polska forsując wolnościowe podejście do gospodarki w ogóle, zabiegając o wprowadzenie podatku liniowego, obniżając koszty pracy może wskazywać na sprawdzone mechanizmy, które zawsze i wszędzie prowadzą do wzrostu i rozwoju. Uznając naszą misję przyczynimy się do uczynienia z obecnie bezradnej, wiecznie protestującej Europy - nie konkurenta, a liczącego się partnera dla stosunkowo liberalnych, utrzymujących główny ciężar naszej obrony, atlantyckiej cywilizacji - Stanów Zjednoczonych Ameryki Północnej. Jeżeli nawet komuś nie podobają się metody przez nie stosowane, to musi przyznać, że dzisiaj są one jedyną siłą mogącą przeciwstawić się okrutnym wyzwaniom takim jak: głód, terroryzm czy totalitaryzm.

Nie znaczy to jednak, że z krajami Wschodu takimi jak Rosja, Chiny czy kraje arabskie nie możemy utrzymywać poprawnych stosunków, jak inni zarabiać, wykazując przy tym tradycyjną polską pomysłowość i znajomość tamtejszych realiów. Przyjazna polityka państwa $z$ pewnością znowu obudzi inwencję, skłonność do ryzyka i życiowej niezależności. Sprowadzi też i obcy kapitał. Pojawią się nowe miejsca pracy. Polacy znajdą zatrudnienie u siebie, gdy nasze produkty będą wreszcie tańsze, bardziej konkurencyjne.

Ważną role odegra też edukacja. Wielu ludzi dających i biorących pracę ma szczere chęci i energię, lecz w sytuacjach trudnych, kryzysowych lub bardziej skomplikowanych nie dają sobie oni sobie po prostu rady. Konieczna jest wiedza z dziedziny zarządzania, organizacji pracy, marketingu czy podstawowa znajomość obowiązujących przepisów prawa, co pozwoli skutecznie usuwać problemy i zniwelować niekorzystną różnice sił w warunkach ostrej konkurencji. Niezależnie od stopnia akceptacji unijnej rzeczywistości, doraźnie musimy nauczyć się w niej sprawnie poruszać, wykorzystywać środki z jej budżetu, dawać odpór brutalnym naciskom jakie pojawiają się w przypadku, gdy jakiś element naszego systemu np. wysokość podatków czyni nasze wyroby dla Niemców czy Francuzów zbyt konkurencyjnymi, nie likwidować istniejącego potencjału rolnictwa. Należy przy tym pamiętać, że każda unia, federacja czy liga realizuje zwykle w sposób mniej lub bardziej zawoalowany interesy najsilniejszych jej członków i wyjątków od tej reguły nie ma.

Tak więc możemy stwierdzić, że polska przedsiębiorczość w przewidywanym okresie zmian cywilizacyjnych na świecie, ma do odegrania szczególną rolę zarówno wymiarze krajowym, jak i międzynarodowym. Nasze położenie pomiędzy Wschodem a Zachodem, dziś może dać nam do ręki niezwykłe atuty i możliwości, stać się przyczyną dostatku pol- 
skich rodzin. Możemy wręcz ozdrowieńczo wpłynąć na systemy tracącej swe historyczne i gospodarcze znaczenie Europy, przyczynić się do zaistnienia prawidłowych relacji z jej głównym sojusznikiem, tj. ze Stanami Zjednoczonymi. Musimy w miarę możliwości wzmocnić ten właśnie układ przed nieuniknioną ekonomiczną konfrontacją $\mathrm{z}$ - dysponującą nie zawsze przecież akceptowanymi przez nas wartościami - cywilizacją Wschodu.

Do tego jednak musimy w Polsce stworzyć wydolny system polityczno-gospodarczy, być silni naszą polską przedsiębiorczością oraz, współpracując z innymi, dbać o polską rację stanu. 